\title{
Sporosarcina macmurdoensis sp. nov., from a cyanobacterial mat sample from a pond in the McMurdo Dry Valleys, Antarctica
}

\author{
Correspondence \\ S. Shivaji \\ shivas@ccmb.res.in
}

\author{
G. S. N. Reddy, ${ }^{1}$ G. I. Matsumoto ${ }^{2}$ and S. Shivaji ${ }^{1}$ \\ ${ }^{1}$ Centre for Cellular and Molecular Biology, Uppal Road, Hyderabad 500 007, India \\ ${ }^{2}$ Department of Environmental and Information Science, Otsuma Women's University, Tamashi, \\ Tokyo 206, Japan
}

\begin{abstract}
Strain CMS $21 \mathrm{w}^{\top}$ was isolated from a cyanobacterial mat sample taken from a pond located in the McMurdo Dry Valleys, Antarctica. Based on its phenotypic, chemotaxonomic and phylogenetic properties, strain CMS $21 w^{\top}$ was identified as a member of the genus Sporosarcina. At the $16 \mathrm{~S}$ rRNA gene level, CMS $21 w^{\top}$ exhibited about 93-96\% similarity to all reported species of Sporosarcina and exhibited a maximum similarity of $96 \%$ to both Sporosarcina globispora and Sporosarcina psychrophila. Based on more than 3\% difference at the 16S rRNA gene sequence level and the presence of distinct differences with respect to phenotypic, biochemical and chemotaxonomic features, strain CMS $21 \mathrm{w}^{\top}\left(=\right.$ MTCC $\left.4670^{\top}=\mathrm{DSM} 15428^{\top}=\mathrm{CIP} 107784^{\top}\right)$ is proposed as the type strain of a novel species of Sporosarcina, Sporosarcina macmurdoensis sp. nov.
\end{abstract}

The genus Sporosarcina, which belongs to the family Bacillaceae, was created by Kluyver \& van Niel (1936) to accommodate bacteria that have spherical or oval-shaped cells, low DNA G $+\mathrm{C}$ content (40-42 mol\%) and MK-7 as the major menaquinone. Sporosarcina species can be differentiated from other members of the Bacillaceae by their coccoid or rod-shaped cells, motility, sporulation and possession of MK-7 as the major menaquinone and $A 4 \alpha$ as the peptidoglycan variant. The genus Sporosarcina originally comprised two species, Sporosarcina ureae and Sporosarcina halophila (Claus et al., 1983; Claus \& Fahmy, 1986). However, three species of the genus Bacillus, namely Bacillus globisporus (Larkin \& Stokes, 1967), Bacillus psychrophilus (Nakamura, 1984) and Bacillus pasteurii (Miguel, 1889), which belonged to rRNA group 2 (Ash et al., 1991) and contain L-lysine in their cell wall, have recently been transferred to the genus Sporosarcina (Yoon et al., 2001) as Sporosarcina globispora, Sporosarcina psychrophila and Sporosarcina pasteurii. Yoon et al. (2001) also identified a novel species, Sporosarcina aquimarina. In continuation of our work on the heterotrophic bacteria associated with cyanobacterial mat samples from the lakes of Antarctica (Reddy et al., 2000, 2002a, 2002b, 2003), seven psychrophilic bacteria from a pond in McMurdo Region, Antarctica, have been identified as strains of Sporosarcina.

Published online ahead of print on 7 February 2003 as DOI 10.1099/ ijs.0.02628-0.

The EMBL/GenBank/DDBJ accession number for the 16S rRNA gene sequence of strain CMS $21 w^{\top}$ is AJ514408.

\section{Source of the organisms, media and growth conditions}

Seven pure cultures (CMS 13, CMS 14, CMS 15, CMS 21w ${ }^{\mathrm{T}}$, CMS 89, CMS 91 and CMS 93) were isolated from cyanobacterial mat samples collected from ponds L4, L8 and E4 of Wright Valley, McMurdo Region, Antarctica (Matsumoto, 1993) according to a previously described procedure (Reddy et al., 2000) using ABM agar ( $0 \cdot 5 \%$ peptone, $0 \cdot 2 \%$ yeast extract and $1.5 \%$ agar, $\mathrm{pH} 7 \cdot 2$; Shivaji et al., 1989). Optimum growth conditions were also determined using $\mathrm{ABM}$ agar plates.

All seven isolates were identical with respect to their colony and cell morphologies, growth requirements, salt tolerance and many biochemical characteristics, suggesting that they are probably strains of the same species. In fact, all seven had identical $16 \mathrm{~S}$ rRNA gene sequences, implying that the seven isolates are clonal in origin. CMS $21 \mathrm{w}^{\mathrm{T}}$ was chosen as a representative strain for detailed studies to establish its identity.

\section{Morphology, motility and biochemical and chemotaxonomic characteristics}

The morphology and motility of CMS $21 \mathrm{w}^{\mathrm{T}}$ were determined by taking exponential-phase cells and observing them by phase-contrast microscopy $(1000 \times)$. Biochemical tests were performed on cultures grown at $20{ }^{\circ} \mathrm{C}$ in nutrient agar $(0 \cdot 5 \%$ peptone, $0 \cdot 3 \%$ beef extract, $0 \cdot 8 \% \mathrm{NaCl}, \mathrm{pH} 7 \cdot 2)$. Catalase, oxidase, phosphatase, gelatinase, urease, lipase, arginine dihydrolase and $\beta$-galactosidase activities were 
determined according to standard methods (Holding \& Collee, 1971). Production of indole, methyl red and VogesProskauer tests, reduction of nitrate to nitrite, hydrolysis of starch and aesculin and production of acid and gas were assessed according to standard procedures (Hugh \& Leifson, 1953; Stanier et al., 1966; Holding \& Collee, 1971; Stolp \& Gadkari, 1981). Antibiotic sensitivity and growth characteristics were analysed using nutrient agar plates and utilization of carbon compounds was determined on minimal medium. The DNA G+C content was determined as described previously (Shivaji et al., 1991).

Fatty acid methyl esters (Sato \& Murata, 1988) were analysed as described previously (Reddy et al., 2002a). Isoprenoid quinones were extracted according to the method described by Collins et al. (1977) and separated by HPLC using an SB$\mathrm{C}_{18}$ Zorbax reverse-phase column $(4 \cdot 6 \times 250 \mathrm{~mm})$ fixed to a Hewlett-Packard series 1100 HPLC connected to a HewlettPackard programmable fluorescence detector (Tamaoka et al., 1982). An isocratic gradient of methanol/isopropyl ether $(3: 1, \mathrm{v} / \mathrm{v})$ was used for elution; the flow rate and filter used were respectively $0.5 \mathrm{ml} \mathrm{min}{ }^{-1}$ and $270 \mathrm{~nm}$. Peptidoglycan was prepared and analysed according to the method described by Komagata \& Suzuki (1987).

Phenotypic and chemotaxonomic characteristics of CMS $21 \mathrm{w}^{\mathrm{T}}$ are described in the species description. From these characteristics, it is apparent that CMS $21 \mathrm{w}^{\mathrm{T}}$, which is rodshaped, non-motile and Gram-positive with subterminal spores, is phenotypically similar to species of the genus Sporosarcina. This was confirmed by chemotaxonomic characteristics such as $\mathrm{A} 4 \alpha$ peptidoglycan variant (with L-Lys-D-Glu peptidoglycan type), MK-7 as the major menaquinone, anteiso- $\mathrm{C}_{15: 0}$ as the major fatty acid and a DNA $\mathrm{G}+\mathrm{C}$ content of $44 \mathrm{~mol} \%$. The phenotypic and chemotaxonomic characteristics that differentiate CMS $21 \mathrm{w}^{\mathrm{T}}$ from the five reported type strains of Sporosarcina and Bacillus insolitus are listed in Table 1.

\section{Phylogenetic analysis}

$16 \mathrm{~S}$ rDNA was amplified, sequenced and analysed as described previously (Shivaji et al., 2000). The partial sequence of the $16 \mathrm{~S}$ rRNA gene containing 1488 bp was aligned with closely related sequences using CLUSTAL W (Thompson et al., 1994). Pairwise evolutionary distances were computed using the DNADIST program with Kimura's two-parameter model (Kimura, 1980) and phylogenetic trees were constructed using four tree-making algorithms (UPGMA, KITCH, FITCH and DNAPARS) (Felsenstein, 1993). Phylogenetic trees were also made using DNADIST, UPGMA and CONSENSE after resampling the data 1000 times using SEQBOOT and bootstrap analysis (Felsenstein, 1993).

BLAST sequence similarity analysis using the 16S rRNA gene sequence indicated that CMS $21 \mathrm{w}^{\mathrm{T}}$ is closely related to Sporosarcina species. This was further confirmed by phylogenetic analysis of the 1488 bp $16 \mathrm{~S}$ rRNA gene sequence of CMS $21 \mathrm{w}^{\mathrm{T}}$ and sequences from species of the genera
Sporosarcina, Bacillus, Caryophanon, Kurthia and Planococcus and by constructing a UPGMA-based phylogenetic tree. The evolutionary distance calculated using Kimura's twoparameter model indicated that CMS $21 \mathrm{w}^{\mathrm{T}}$ is related to species of the genus Sporosarcina (similarity of $93-96 \%$ ) and is most closely related to S. globispora (96\%), S. psychrophila $(96 \%)$ and B. insolitus (96\%). The topology of the phylogenetic tree showed that CMS $21 \mathrm{w}^{\mathrm{T}}$ is closely related to S. globispora (Rüger, 1983), S. psychrophila (Nakamura, 1984), S. aquimarina (Yoon et al., 2001), S. ureae (Claus \& Fahmy, 1986), S. pasteurii (Yoon et al., 2001) and B. insolitus (Rüger, 1983). However, within the cluster, only S. psychrophila and S. globispora had a high bootstrap value $(100 \%)$; this value varied from 40 to $60 \%$ with the other species (Fig. 1). All the different algorithms used for tree construction gave comparable branching patterns. However, CMS $21 \mathrm{w}^{\mathrm{T}}$ cannot be grouped with B. insolitus since the latter strain has ornithine in its peptidoglycan, unlike all reported species of Sporosarcina, which contain lysine (Yoon et al., 2001). Furthermore, inclusion of $B$. insolitus in the cluster is not very robust, having a low bootstrap value of $55 \%$ with strain CMS $21 w^{\mathrm{T}}$.

\section{Conclusions}

CMS $21 w^{T}$ is a Gram-positive, non-motile rod with subterminal spores, L-Lys-D-Glu peptidoglycan, MK-7 as the menaquinone, anteiso- $\mathrm{C}_{15: 0}$ as the major fatty acid and a DNA G + C content of $44 \mathrm{~mol} \%$, thus exhibiting phenotypic and chemotaxonomic characteristics of the genus Sporosarcina. However, at the 16S rRNA gene level, CMS $21 \mathrm{w}^{\mathrm{T}}$ exhibits about $96 \%$ similarity to both S. globispora and $S$. psychrophila and the similarity is even lower to S. aquimarina $(94 \cdot 6 \%)$, S. pasteurii $(93 \%)$ and S. ureae $(95 \%)$. Therefore, considering that CMS $21 \mathrm{w}^{\mathrm{T}}$ differs from all reported species by more than $3 \%$ at the $16 \mathrm{~S}$ rRNA gene level, it is unlikely to have DNA-DNA similarities of more than $70 \%$ (Stackebrandt \& Goebel, 1994). Therefore, it would appear that CMS $21 \mathrm{w}^{\mathrm{T}}$ represents a novel species of Sporosarcina. Further evidence that CMS $21 \mathrm{w}^{\mathrm{T}}$ represents a novel species comes from differences in phenotypic characteristics (Table 1). CMS $21 \mathrm{w}^{\mathrm{T}}$ is unique in that it has both anteiso- $\mathrm{C}_{15: 0}$ and iso- $\mathrm{C}_{16: 1}$ as major fatty acids, whereas other species of the genus Sporosarcina have only antesio$\mathrm{C}_{15: 0}$ as the major fatty acid (Yoon et al., 2001). CMS $21 \mathrm{w}^{\mathrm{T}}$ also contains $C_{15: 1}$, which is absent in other species of the genus Sporosarcina. Furthermore, in B. insolitus, the major fatty acids are iso- $\mathrm{C}_{15: 0}$, anteiso- $\mathrm{C}_{15: 0}$ and $\mathrm{C}_{16: 1}$ (Kaneda et al., 1983). Therefore, CMS $21 \mathrm{w}^{\mathrm{T}}$ is proposed as the type strain of a novel species of the genus Sporosarcina, Sporosarcina macmurdoensis sp. nov.

\section{Description of Sporosarcina macmurdoensis sp. nov.}

Sporosarcina macmurdoensis (mac.mur.do.en'sis. N.L. fem. adj. macmurdoensis pertaining to the McMurdo Region, Antarctica, where the isolates were collected). 
Table 1. Phenotypic characteristics that differentiate $S$. macmurdoensis sp. nov. CMS $21 w^{\top}$ from type strains of related species

Strains/species: 1, CMS 21w ${ }^{\mathrm{T}}$; 2, S. psychrophila (Nakamura, 1984); 3, S. globispora (Nakamura, 1984; Rüger, 1983); 4, S. aquimarina (Yoon et al., 2001); 5, S. pasteurii (Yoon et al., 2001); 6, S. ureae (Claus \& Fahmy, 1986); 7, B. insolitus (Claus \& Berkeley, 1986). +, Positive; -, negative; NA, data not available. For all strains, the major menaquinone is MK-7.

\begin{tabular}{|c|c|c|c|c|c|c|c|}
\hline Characteristic & 1 & 2 & 3 & 4 & 5 & 6 & 7 \\
\hline Colony colour & White & White & White & Light orange & White & White & NA \\
\hline Cell shape & Rods & Rods & Rods & Rods & Spherical & Spherical & Rods \\
\hline Optimum $\mathrm{pH}$ for growth & 7 & 7 & 7 & $6 \cdot 5-7 \cdot 0$ & 9 & 7 & $6-7$ \\
\hline \multicolumn{8}{|l|}{ Growth at $\left({ }^{\circ} \mathrm{C}\right)$ : } \\
\hline 37 & - & - & - & + & + & + & - \\
\hline $\begin{array}{l}\text { Optimum growth temperature } \\
\left({ }^{\circ} \mathrm{C}\right)\end{array}$ & 20 & 25 & 20 & 25 & 30 & 25 & 25 \\
\hline \multicolumn{8}{|l|}{ Presence of: } \\
\hline$\beta$-Galactosidase & - & + & + & NA & NA & NA & NA \\
\hline Nitrate reduction & + & + & - & + & + & - & - \\
\hline DNA G $+\mathrm{C}$ content $(\mathrm{mol} \%)$ & 44 & $44 \cdot 1$ & 40 & 40 & 39 & $40-42$ & $35 \cdot 9$ \\
\hline Peptidoglycan type & L-Lys-D-Glu & L-Lys-D-Glu & L-Lys-D-Glu & L-Lys-Ala-Asp & L-Lys-D-Asp & L-Lys-Gly-Glu & D-Orn-D-Glu \\
\hline Peptidoglycan variant & $\mathrm{A} 4 \alpha$ & $\mathrm{A} 4 \alpha$ & $\mathrm{A} 4 \alpha$ & $\mathrm{A} 4 \alpha$ & $\mathrm{A} 4 \alpha$ & $\mathrm{A} 4 \alpha$ & $\mathrm{A} 4 \beta$ \\
\hline Major fatty acids* & $\mathrm{aiC}_{15: 0}, \mathrm{iC}_{16: 1}$ & $\mathrm{aiC}_{15: 0}$ & $\mathrm{aiC}_{15: 0}$ & $\mathrm{aiC}_{15: 0}$ & $\mathrm{aiC}_{15: 0}$ & $\mathrm{aiC}_{15: 0}$ & $\begin{array}{c}\mathrm{iC}_{15: 0}, \text { aiC }_{15: 0} \\
\mathrm{C}_{16: 1}\end{array}$ \\
\hline \multicolumn{8}{|l|}{ Acid production from: } \\
\hline D-Fructose & - & + & - & + & NA & NA & NA \\
\hline D-Galactose & - & + & - & - & NA & NA & $\mathrm{NA}$ \\
\hline D-Glucose & - & + & + & - & $\mathrm{NA}$ & NA & - \\
\hline Lactose & - & - & + & - & NA & NA & - \\
\hline D-Glucose & + & + & - & NA & NA & NA & NA \\
\hline D-Maltose & + & - & - & NA & NA & NA & NA \\
\hline D-Xylose & + & + & - & NA & NA & NA & NA \\
\hline
\end{tabular}

*ai, Anteiso; i, iso.

Colonies are circular, flat, irregular, opaque and white with a diameter of 2-3 mm. Cells are rod-shaped, single and nonmotile and form subterminal spores. Cells can tolerate a maximum of $3 \%(\mathrm{w} / \mathrm{v}) \mathrm{NaCl}$ and grow at $\mathrm{pH} 6-9(\mathrm{pH} 7$ is optimum for growth). Psychrophilic; grows at $4-25^{\circ} \mathrm{C}$ (optimum growth temperature $18-20^{\circ} \mathrm{C}$ ). Positive for catalase, phosphatase, gelatinase and starch hydrolysis and negative for lipase, urease, oxidase, $\beta$-galactosidase, arginine dihydrolase, arginine decarboxylase, lysine decarboxylase, indole production, methyl red test, Voges-Proskauer test, aesculin hydrolysis and nitrate reduction to nitrite. Does not produce acid or gas from L-arabinose, D-fructose, D-galactose, lactose, D-mannose, D-mannitol, L-rhamnose, sucrose or D-xylose. Utilizes dulcitol, D-fructose, D-galactose, D-glucose, meso-inositol, lactose, D-maltose, D-mannose, pyruvate, D-raffinose, D-xylose and L-glutamic acid as sole carbon sources, but not acetate, adonitol, L-arabinose, D-cellobiose, cellulose, citrate, dextran, glucose, 


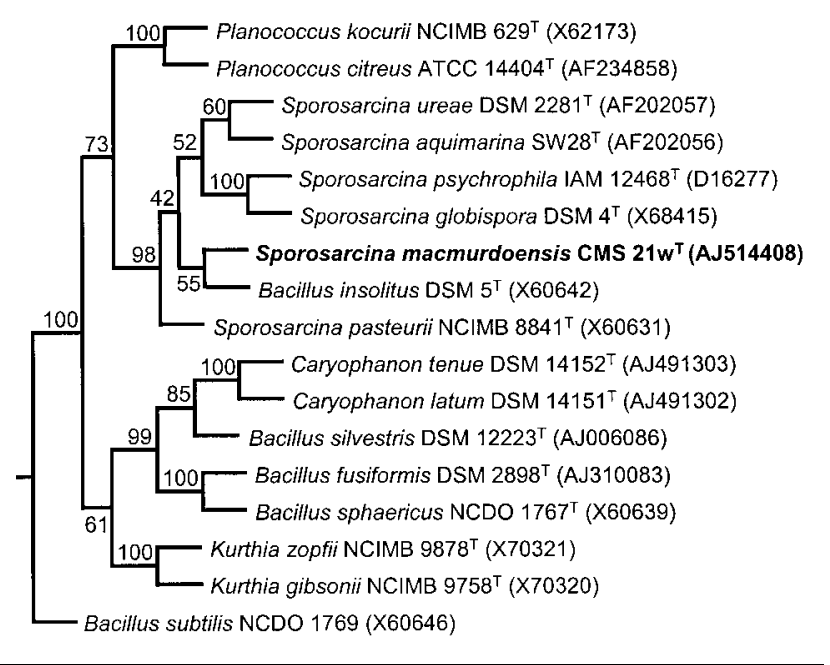

Fig. 1. Phylogenetic relationship between Sporosarcina macmurdoensis sp. nov. CMS $21 \mathrm{w}^{\top}$ and other related reference micro-organisms in the genera Bacillus, Caryophanon, Kurthia and Planococcus based on 16S rRNA gene sequence analysis using UPGMA. Bootstrap values (\%) are given at nodes. Branch lengths are not to scale.

meso-erythritol, fumaric acid, glycerol, inulin, lactic acid, D-mannitol, D-melibiose, melezitose, L-rhamnose, D-ribose, sorbitol, D-sorbose, sucrose, succinic acid, trehalose, thioglycollate, L-alanine, L-arginine, L-aspartic acid, L-aspargine, L-glutamine, L-lysine, L-histidine, L-isoleucine, L-leucine, L-lysine, L-methionine, L-phenylalanine, L-proline, L-serine, L-threonine, L-tyrosine, L-tryptophan or L-valine. Sensitive to amikacin, ampicillin, amoxycillin, bacitracin, carbenicillin, cefazoline, cefaperazone, cephotaxime, chloramphenicol, chlorotetracycline, co-trimoxazole, ciprofloxacin, erythromycin, furazolidone, furoxone, gentamicin, kanamycin, lomefloxacin, nalidixic acid, neomycin, nitrofurazone, nitrofurantoin, norfloxacin, novobiocin, nystatin, oxytetracycline, penicillin, polymyxin-B, rifampicin, roxithromycin, streptomycin, tetracycline, tobramycin, trimethoprim and vancomycin, but resistant to cefuroxime, colistin and lincomycin. Peptidoglycan type is L-Lys-D-Glu of the A $4 \alpha$ variant and MK-7 is the major menaquinone. When grown in nutrient broth at $22^{\circ} \mathrm{C}$, the fatty acid composition is as follows (proportions of total fatty acids in parentheses): $\mathrm{C}_{13: 0}(0.5 \%), \mathrm{C}_{14: 0}(0.5 \%)$, iso- $\mathrm{C}_{14: 0}$ $(11 \cdot 1 \%), \mathrm{C}_{15: 0}(1 \cdot 1 \%)$, iso- $\mathrm{C}_{15: 0}(4 \cdot 0 \%)$, anteiso- $\mathrm{C}_{15: 0}$ $(37 \cdot 4 \%), \mathrm{C}_{15: 1}(1 \cdot 5 \%), \mathrm{C}_{16: 0}(0 \cdot 7 \%)$, iso- $\mathrm{C}_{16: 0}(3 \cdot 2 \%)$, $\mathrm{C}_{16: 1} \omega 7 c(1 \cdot 1 \%)$, iso- $\mathrm{C}_{16: 1}(22 \cdot 6 \%)$, iso- $\mathrm{C}_{17: 0}(3 \cdot 0 \%)$ and anteiso- $\mathrm{C}_{17: 0}(13 \cdot 0 \%)$.

The DNA $\mathrm{G}+\mathrm{C}$ content of the type strain, CMS $21 \mathrm{w}^{\mathrm{T}}$ $\left(=\right.$ MTCC $\left.4670^{\mathrm{T}}=\mathrm{DSM} 15428^{\mathrm{T}}=\mathrm{CIP} 107784^{\mathrm{T}}\right)$, is $44 \mathrm{~mol} \%$.

\section{Acknowledgements}

This work was supported by a grant from the Department of Biotechnology, Government of India.

\section{References}

Ash, C., Farrow, J. A. E., Wallbanks, S. \& Collins, M. D. (1991). Phylogenetic heterogeneity of the genus Bacillus as revealed by comparative analysis of small-subunit-ribosomal RNA sequences. Lett Appl Microbiol 13, 202-206.

Claus, D. \& Berkeley, R. C. W. (1986). Genus Bacillus Cohn 1872, $174^{\mathrm{AL}}$. In Bergey's Manual of Systematic Bacteriology, vol. 2, pp. 1105-1139. Edited by P. H. A. Sneath, N. S. Mair, M. E. Sharpe \& J. G. Holt. Baltimore: Williams \& Wilkins.

Claus, D. \& Fahmy, F. (1986). Genus Sporosarcina Kluyver and van Niel 1936, 401 ${ }^{\mathrm{AL}}$. In Bergey's Manual of Systematic Bacteriology, vol. 2, pp. 1202-1206. Edited by P. H. A. Sneath, N. S. Mair, M. E. Sharpe \& J. G. Holt. Baltimore: Williams \& Wilkins.

Claus, D., Fahmy, F., Rolf, H. J. \& Tosunoglu, N. (1983). Sporosarcina halophila sp. nov., an obligate, slightly halophilic bacterium from salt marsh soils. Syst Appl Microbiol 4, 496-506.

Collins, M. D., Pirouz, T., Goodfellow, M. \& Minnikin, D. E. (1977). Distribution of menaquinones in actinomycetes and corynebacteria. J Gen Microbiol 100, 221-230.

Felsenstein, J. (1993). PHYLIP (phylogenetic inference package), version 3.5c. Department of Genetics, University of Washington, Seattle, WA, USA.

Holding, A. J. \& Collee, J. G. (1971). Routine biochemical tests. Methods Microbiol 6A, 2-32.

Hugh, R. \& Leifson, E. (1953). The taxonomic significance of fermentative versus oxidative metabolism of carbohydrates by various gram-negative bacteria. J Bacteriol 66, 24-26.

Kaneda, T., Smith, E. J. \& Naik, D. N. (1983). Fatty acid composition and primer specificity of de novo fatty acid synthetase in Bacillus globisporus, Bacillus insolitus and Bacillus psychrophilus. Can J Microbiol 29, 1634-1641.

Kimura, M. (1980). A simple method for estimating evolutionary rates of base substitutions through comparative studies of nucleotide sequences. J Mol Evol 16, 111-120.

Kluyver, A. J. \& van Niel, C. B. (1936). Prospects for a natural classification of bacteria. Zentbl Bakteriol Parasitenkd Infektkrankh Hyg Abt II 94, 369-403.

Komagata, K. \& Suzuki, K. (1987). Lipid and cell-wall analysis in bacterial systematics. Methods Microbiol 19, 161-206.

Larkin, J. M. \& Stokes, J. L. (1967). Taxonomy of psychrophilic strains of Bacillus. J Bacteriol 94, 889-895.

Matsumoto, G. I. (1993). Geochemical features of the McMurdo Dry Valley lakes, Antarctica. Physical and biogeochemical processes in Antarctic lakes. Antarct Res Ser 49, 95-118.

Miquel, P. (1889). Étude sur la fermantation ammoniacale et sur les ferments de l'urée. Ann Microgr 1, 506-519.

Nakamura, L. K. (1984). Bacillus psychrophilus sp. nov., nom. rev. Int J Syst Bacteriol 34, 121-123.

Reddy, G. S. N., Aggarwal, R. K., Matsumoto, G. I. \& Shivaji, S. (2000). Arthrobacter flavus sp. nov., a psychrophilic bacterium isolated from a pond in McMurdo Dry Valley, Antarctica. Int J Syst Evol Microbiol 50, 1553-1561.

Reddy, G. S. N., Prakash, J. S. S., Matsumoto, G. I., Stackebrandt, E. \& Shivaji, S. (2002a). Arthrobacter roseus sp. nov., a psychrophilic bacterium isolated from an Antarctic cyanobacterial mat sample. Int J Syst Evol Microbiol 52, 1017-1021.

Reddy, G. S. N., Prakash, J. S. S., Vairamani, M., Prabahar, S., Matsumoto, G. I. \& Shivaji, S. (2002b). Planococcus antarcticus and Planococcus psychrophilus spp. nov. isolated from cyanobacterial mat samples collected from ponds in Antarctica. Extremophiles 6, 253-261. 
Reddy, G. S. N., Prakash, J. S. S., Prabahar, V., Matsumoto, G. I., Stackebrandt, E. \& Shivaji, S. (2003). Kocuria polaris sp. nov., an orange-pigmented psychrophilic bacterium isolated from an Antarctic cyanobacterial mat sample. Int J Syst Evol Microbiol 53, 183-187.

Rüger, H.-J. (1983). Differentiation of Bacillus globisporus, Bacillus marinus comb. nov., Bacillus aminovorans, and Bacillus insolitus. Int J Syst Bacteriol 33, 157-161.

Sato, N. S. \& Murata, N. (1988). Membrane lipids. Methods Enzymol 167, 251-259.

Shivaji, S., Rao, N. S., Saisree, L., Sheth, V., Reddy, G. S. N. \& Bhargava, P. M. (1989). Isolation and identification of Pseudomonas spp. from Schirmacher Oasis, Antarctica. Appl Environ Microbiol 55, $767-770$.

Shivaji, S., Ray, M. K., Kumar, G. S., Reddy, G. S. N., Saisree, L. \& Wynn-Williams, D. D. (1991). Identification of Janthinobacterium lividum from the soils of the islands of Scotia Ridge and from Antarctic peninsula. Polar Biol 11, 267-272.

Shivaji, S., Bhanu, N. V. \& Aggarwal, R. K. (2000). Identification of Yersinia pestis as the causative organism of plague in India as determined by $16 \mathrm{~S}$ rDNA sequencing and RAPD-based genomic fingerprinting. FEMS Microbiol Lett 189, 247-252.

Stackebrandt, E. \& Goebel, B. M. (1994). Taxonomic note: a place for DNA-DNA reassociation and $16 \mathrm{~S}$ rRNA sequence analysis in the present species definition in bacteriology. Int J Syst Bacteriol 44, 846-849.

Stanier, R. Y., Palleroni, N. J. \& Doudoroff, M. (1966). The aerobic pseudomonads: a taxonomic study. J Gen Microbiol 43, 159-271.

Stolp, H. \& Gadkari, D. (1981). Nonpathogenic members of the genus Pseudomonas. In The Prokaryotes, vol. 1, pp. 719-741. Edited by M. P. Starr, H. Stolp, H. G. Trüper, A. Balows \& H. G. Schlegel. Berlin: Springer.

Tamaoka, J., Katayama-Fujimura, Y. \& Kuraishi, H. (1982). Analysis of bacterial menaquinone mixtures by high performance liquid chromatography. J Appl Bacteriol 54, 31-36.

Thompson, J. D., Higgins, D. G. \& Gibson, T. J. (1994). CLUSTAL W: improving the sensitivity of progressive multiple sequence alignment through sequence weighting, position-specific gap penalties and weight matrix choice. Nucleic Acids Res 22, 4673-4680.

Yoon, J.-H., Lee, K.-C., Weiss, N., Kho, Y. H., Kang, K. H. \& Park, Y.-H. (2001). Sporosarcina aquimarina sp. nov., a bacterium isolated from seawater in Korea, and transfer of Bacillus globisporus (Larkin \& Stokes 1967), Bacillus psychrophilus (Nakamura 1984) and Bacillus pasteurii (Chester 1898) to the genus Sporosarcina as Sporosarcina globispora comb. nov., Sporosarcina psychrophila comb. nov. and Sporosarcina pasteurii comb. nov., and emended description of the genus Sporosarcina. Int J Syst Evol Microbiol 51, 1079-1086. 